\title{
American Corn in Russia: Lessons of the People-to-People Diplomacy and Capitalism
}

\author{
Victoria I. Zhuravleva
}

This paper is devoted to the "corn diplomacy" in the context of Russian-American relations from the end of the $19^{\text {th }}$ century to the Cold war period. The author focuses her attention on three cases dealt with the American attempts to export their corn and secrets of corn production to the Russian Empire and the Soviet Union. These thematic priorities give her the brilliant opportunity to analyze two dimensions of American messianic feelings determined the stable long-term perception trends of Russia in the American society. The economic one arose from the attractive prospects of exports of goods, capital, and technologies into Russian markets (Russia was supposed to learn "the lessons of American capitalism"). The humanitarian one turned a famished and backward Russia into the object of aid from the rich and prosperous America and the Americans - into "international philanthropists". At the same time one of the main author's conclusions is that the "corn diplomacy" played an important role in promoting better understanding between Russian and Americans became the equivalent of the people-to-people diplomacy.

Key words: Russian/Soviet-American relations; "corn diplomacy", people-to-people diplomacy, images of the Russian Empire and the Soviet Union in the United States

In August 2009, the State of Iowa commemorated the $50^{\text {th }}$ anniversary of Nikita Sergeevich Khrushchev's visit to the farm of Roswell Garst, the very man who had offered to teach the Soviet leader how to cultivate hybrid corn varieties that would boost livestock production and provide a plentiful supply of meat for the Soviet people. In those days, the Soviet periodicals were full of effusive articles describing Garst's innovative method, and whole books were written about his corn-based farming. The man himself was a welcome guest in Kremlin, as he gladly gave lessons in capitalist agricultural production and acted as a people's diplomat in the middle of the Cold War.

Yet the story of how American corn science "conquered" Russia had begun long before Khrushchev's visit to Iowa. Its first episode came in 1892, with the upsurge of a US movement to help the starving Russian peasants. In retrospect, the American eagerness to feed Russia with American corn was a strategy that allowed, on the one hand, to propagate the new method of people-to-people diplomacy that had contributed to a better understanding between the two nations, and on the other hand, to bolster the image of America as the land of plenty that was eager to feed the whole world and of Russians as students that had to be taught the secrets of American success. 
The relief movement provided new impulses for the American messianic feelings that emerged at the turn of the $20^{\text {th }}$ century, were correlated with the prospects of Russian modernization, and have not lost their importance until our days. These messianic moods had four dimensions that originated from the sociocultural characteristics of the American society itself and also from the agenda of its own development. The first dimension was a political one and consisted in the opposition to the Russian political regime and in the sense of responsibility for the process of its formation in the context of the US global democratization mission; thus, the Americans appeared in the role of "political mentors." The second one arose from the attractive prospects of economic expansion, exports of goods, capital, and technologies into Russian markets, and participation in the modernization of Russian economy; Russia was supposed to learn "the lessons of American capitalism." Religion provided the third dimension: the goal of replacing the Orthodox faith with a rational one and the projection of the Manichean worldview on the positioning of the Russian image allowed the Americans to present themselves as "the bearers of true faith." Finally, the humanitarian dimension turned a famished and poverty-stricken Russia into the object of aid from the rich and prosperous America and the Americans - into “international philanthropists.

\section{A story about the Nebraska and Iowa farmers who shared their corn with the Russian peasants}

The American relief movement that surged during the 1891-1892 Russian Famine holds a special place in the history of Russian-American relations. It was the first example of people-to-people diplomacy in action, since the famine aid came from grassroots groups and individual States. It was also the first international humanitarian action of such scale both for the American National Red Cross (ANRC) and for the United States in general. The relief movement mixed and superimposed the old and the new images of the Russian Empire, emphasized its backwardness and helped Americans to become more familiar with the Russian national character.

This humanitarian action was in part responsible for the connection that began to emerge in the US social consciousness between the idea of searching for "free markets" and the sense of the American national mission to liberate the world. ${ }^{1}$ Idealism and pragmatism intertwined in the motivations of the relief movement participants, who were moved both by profit-seeking and altruism. Such a mixed motivation was typical for the American nation in general. The great American writer Herman Melville embodied this idea in chapter 36 of The White Jacket: "And let us always remember that with ourselves, almost for the first time in the history of earth, national selfishness is unbounded philanthropy; for we cannot do a good to America but we give alms to the world."

\footnotetext{
1 For instance, William Williams, a well-known American historian, insisted that the participants of the philanthropic movement were moved by a double motive: the opening of new markets and the promotion of liberty. See Williams W.A. The Roots of the Modern American Empire: A Study of the Growth and Shaping of Social Consciousness in a Marketplace Society. N.Y.: Random House, 1959. P. 293-294, 342-343.
} 
The famine relief campaign for the benefit of Russian peasants took shape in early December 1891, after the Russian Charge d'Affairs Alexander Greger told William Edgar, the editor of the weekly trade journal "Northwestern Miller", that a cargo of corn flour was a form of aid that would be both timely and wellreceived by the Tsar's government that was willing to pay for the transport of food donations from the US interior regions to New York City and from there- to the shores of the Russian Empire. ${ }^{2}$

Edgar became the head of the first Russian Famine Relief Committee that was created in Minnesota in December 1891, after the state governor had made an appeal, reminding Americans about Russia's contribution to the Union cause during the American Civil War of 1861-1865. John M. Thayer, the governor of the "corn" state of Nebraska soon followed Edgar's example. After the Governor had made his appeal, the Nebraska State Journal published an article whose author argued that relieving famine in Russia would "call the attention of the world to the corn products of the United States" and "open the way for the introduction of American corn...to the people of Europe". ${ }^{3}$ Following Merriam's and Edgar's suggestion, the Russian Famine Relief Committee of Nebraska, headed by L.P. Ludden, started to collaborate closely with the Russian Famine Relief Committee of Minnesota in the task of collecting and sending food aid. ${ }^{4}$

In December 1891, another "corn state"-Iowa — emerged as the second important center of this philanthropic campaign. After an appeal issued by the Iowa governor Horace Boies, Benjamin Franklin Tillinghast, the editor of "The Davenport Democrat" and Alice French - a writer well known by her pen name of Octave Thanet- - had created the Iowa Russian Famine Relief Commission that came to collaborate actively with the ANRC in sending whole corn and cornmeal to the famished Russian peasants. ${ }^{5}$ After she had received assurances from James G. Blaine, the US Secretary of State, and Alexander Greger that the Russian government was ready to receive famine aid from the American people, Clara Barton, the president of the ANRC, also became an active member of the movement and her organization became an important center for money donations. ${ }^{6}$

2 Correspondence between William Edgar and Alexander Greger can be found in: Arkhiv vneshnei politiki Rossiiskoi imperii (AVPRI). F. Posol'stva v Vashingtone. Op. 512/1. D. 737. L. 201-203, 222-223, 225-229.

3 Governor Thayer's Appeal // The Nebraska State Journal, December 20, 1891. P. 8.

4 Letter from W. Edgar to J.M. Thayer, 23 December 1891; letter from W.P. Merriam to J.M. Thayer, 26 December 1891. // State Archives of Nebraska. Nebraska State Historical Society. RG.1. State Governor. 14. Series 1. Box 8; letter from J.M. Thayer to A.E. Greger, 26 December 1891; letter from J.M. Thayer to W.P. Merriam, 28 December 1891. // Ibid., Box 11. Letter press book. Vol. 1891-1892. P. 89, 95.

5 The Davenport Democrat. Nov. 23, 1891; Tillinghast B.F. A Far-Reaching Charity I // Midland Monthly. 1894. April. Vol. 1. N 4. P. 330-331.

6 AVPRI. F. Posol'stva v Vashingtone. Op. 512/1. D. 56. L. 73-74 ob.; D. 737. L. 2 , 124, 126, 130-131ob.; letter from C. Barton to J.G. Blaine, 14 December 1891. // Library of Congress (LC). Manuscript Division (MD). Clara Barton Papers. R. 83; letter from C. Barton to A.E. Greger, 1 January 1892 // Ibid., R. 26. 
From the very beginning, organizers and participants of this philanthropic campaign confronted staunch opposition and harsh criticisms from the members of the first American "crusade" for the cause of Russian freedom, initiated by the liberal journalist George Kennan, after he had returned from a journey through Siberia. This "crusade" was supported by Russian political emigrants and also by progressive public and religious figures within the American society. In 1891, these communities joined their forces and formed the Society of American Friends of Russian Freedom that began to promote its vision on the pages of "Free Russia". Just as the Russian famine relief efforts were beginning to take shape, the Friends of Russian Freedom were mobilizing the American public opinion against the ratification of the Russian-American Extradition Treaty that the US and the Russian governments had signed in 1887 and that, if ratified by the US Congress, would oblige the US to hand over to the Russian authorities all individuals allegedly involved in regicide. This anti-extradition campaign had put the finishing touches on the "demonic" image of the official Russia as a prison for political and religious dissidents. ${ }^{7}$

Although newspapers and journals published numerous articles on the subject of "the Russian famine", William Edgar remarked that "the general tone of the press throughout the country . . . was scarcely encouraging, as it varied from mere tolerance of the idea [that America should help to alleviate it] to severe criticism". 8 The consensus in the American press was that it was senseless and unbecoming for Americans to be helping a government that sent its most energetic and enlightened subjects to Siberia, treated the Jews so harshly that they were forced to emigrate to the US, continued to rob its peasants, and whose actions had not only failed to alleviate the famine but instead led to bribery and speculation. The opponents of the famine relief campaign appealed to ideological considerations, arguing that it was morally wrong for a free and democratic republic to be helping a despotic and arbitrary empire. Meanwhile, the advocates of famine relief argued, following Edgar's lead, that the question was not a political, but a humanitarian one. "The Northwestern Miller" and "Free Russia" became the main poles of this polemic whose origins remounted to drastically different positioning and images of Russia that existed in American representations. ${ }^{9}$

The House of Representatives of the US Congress became another arena of confrontation for the radically different approaches to the question of famine re-

7 On the first American "crusade" for the advancement of democracy in Russia in general and about the campaign against the ratification of the Russian-American Extradition Treaty in particular, see Zhuravleva V.I. Understanding Russia in the USA: Images and Myths. 1881-1914. Moscow: RGGU, 2012. P. 149-209; Foglesong D.S. The American Mission and the «Evil Empire». The Crusade for a «Free Russia» since 1881. N.Y.: Cambridge University Press, 2007. P. 16-27.

8 Edgar W. C. The Russian Famine of 1891 and 1892: Some Particulars of the Relief Sent to the Destitute Peasants by the Millers of America in the Steamship Missouri. Minneapolis: Millers and Manufacturers Insurance, 1893. P. 9.

9 See, for example, Free Russia. 1891. September. P. 6-7; October. P. 7, November. P. 3-4, December. P. 5; 1892. January. P. 4-5; March. P. 8, April. P. 4; May. P. 10; The Northwestern Miller. February 19, 1892. Vol. 33. N 8. P. 265. 
lief for Russian peasants. The organizers of the philanthropic campaign argued that it had to be an American undertaking from the beginning to the end and asked for public funds to ship the food donations across the Atlantic. After much debate, the Congress had not authorized the appropriation of 100 thousand dollars by the Department of the Navy for the freightage of a ship. Due to the opposition of Democrats and Populists, the question of whether the US Federal Government would participate in the famine relief effort got postponed indefinitely. ${ }^{10}$

Yet, neither the press critics, nor the opposition in the House of Representatives could stall the momentum of the campaign. Its participants were driven by the ideals of humanism and compassion, but they also made references to the traditionally friendly relations between the two countries and to the image of Russia as a country that had always come to America's aid at critical moments of its history, be it during the War of Independence or the Civil War of 1861-65. They felt that it was inappropriate and humiliating to ask the Russian government for money to transport the food aid. Faced with a recalcitrant Congress, they decided to launch a large-scale public fundraising campaign in order to finance the freighting of the ships. Thus the relief campaign became a true effort of one people to help another.

The Russian Famine Relief Committee of the United States began its work in January 1892 and became the coordination center for the entire campaign, while working in close collaboration with the ANRC. It was directed by John W. Hoyt, an ex-governor of the Wyoming Territory and former editor of the "Wisconsin Farmer and Northwestern Cultivator" journal. Hoyt was a man of ample international experience, who had traveled far and wide and had visited the Russian Empire.

Farmers and millers in Minnesota, Iowa, and Nebraska sprang into action, hoping to put together a ship-load of corn and wheat flour for Russia in the shortest possible time. However, their efforts were delayed by the vastness of the North-Western states, the weather conditions, and the transport difficulties. The Eastern states were able to act faster, and Pennsylvania soon emerged as a true leader of the famine relief movement and opened the third Russian Famine Relief center - after Minnesota and Iowa.

In early February 1892, Mayor Edwin S. Stuart spearheaded the creation of the Famine Relief Association of the City of Philadelphia. One of its members, Rudolf Blankenburg, a Quaker, a well-known reformer, and himself a future Philadelphia mayor, put together and published a special pamphlet with a characteristic title: "Shall Russian Peasants Die of Starvation? A Question for Prosperous America." "In three weeks, the Association had managed to collect nearly $\$ 100.000$ in cash and to purchase over 2.000 tons of meal products in various locations throughout the country. These were shipped free of charge by fast freight schedule over several railroad lines that converged on Philadelphia. The

${ }^{10}$ Congressional Record. 52-nd Congress. 1-st Session. Vol. 23. Pt. 1. P.110-111, 157177.

${ }^{11}$ Saul N.E. Concord and Conflict. The United States and Russia, 1867-1914. Lawrence: University Press of Kansas, 1996. P. 345. 
International Navigation Company had donated the use of its steamship "Indiana", assuming all costs of the voyage; the Sterling Coal Company had filled her bankers with sufficient coal for the entire outward trip, free of charge, the grocers and provision dealers had donated food for the entire crew that had volunteered their services.

On February 22 2 nd, 1892 , on George Washington's birthday, the steamship "Indiana" departed from Philadelphia for its destination-the Russian port of Libava, amid the cheers of 50 thousand enthusiastic spectators. Church ministers of various denominations presided over a farewell ceremony that left a lasting impression on everyone in attendance. Two months later, on the $23^{\text {rd }}$ of April, the Philadelphia Association sent another steamship, "Conemaug" that carried 2.652.73 tons of flour and other stores. The use of this steamer was donated by the International Company under the same conditions that were used for "Indiana". ${ }^{12}$ During these months, the press of New York, Philadelphia, Chicago, and Washington finally began to turn around and to support the philanthropic campaign, thereby helping to popularize it further. ${ }^{13}$

In early March of 1892, the State Committees of Minnesota and Nebraska had successfully accomplished their mission and got the steamship "Missouri" ready for its journey to Russia. Nebraska alone had contributed 1.350 .000 pounds of corn to this effort. On 17 February 1892, this bounty was sent out of Lincoln and Omaha in two trains that were fittingly decorated for the occasion and covered with banners that read: "Nebraska can feed the world-1891 menu, 165.000,000 bushels of corn", "Nebraska is the home of King Corn", "Nebraska to RussiaLive and help live", "King Corn of Nebraska-His credentials to the czar of the Russian", "Prosperous Nebraska extends greeting and sympathy to the famine stricken Russians", "Patriotic Nebraska with gratitude for Russia's sympathy for the Union in the dark days of war". Each sack of corn contained a booklet of simple cornmeal recipes translated into Russian. ${ }^{14}$ Forethoughtful American donors were conscious of the fact that Russians were unfamiliar with this cereal that could provoke indigestion, if badly cooked.

All in all, "Missouri" carried 5.900.000 pounds of flour and corn meal. The deadline for the collection was February $12^{\text {th }}$, since the freight sent after that date

${ }^{12}$ AVPRI. F. Posol'stva v Vashingtone. Op. 512/1. D. 55. L. 30; D. 737. L. 85-87, 98, 106 ob., 116, 124-125; Harper's Weekly. March 5, 1892. P. 223; Reeves F.B. Russia Then and Now. 1892-1917. N.Y. N.Y., L.: Putman's, 1917. P. 3-5, 7-8; Blankenburg R. Philadelphia and the Russian Famine of 1891 and 1892. Letters from Russia to the Philadelphia "Ledger", "Times" and "Inquirer". Philadelphia: Russian Famine Relief Committee, 1892. P. 58-59; The Philadelphia Public Ledger. April 25, 1892.

${ }^{13}$ See for example: The New York Tribune. February 6, 13, 1892; The New York Herald. March 6, 8, 1892; The New York Times. February 5, 18, 1892; The New York World. May 3, 1892; The Philadelphia Public Ledger. February 1, 1892; The Washington Star. March 12, 1892; The Washington Post. February 1, 1892; The Chicago Times. April 2, 1892; The Chicago Daily Tribune. February 15, 1892.

${ }_{14}$ The Nebraska State Journal. February 16, 1892. P. 2; February 17. P. 7; Ludden L. $P$. Report of the Work in Nebraska for the Russian Famine Sufferers to the Governor of the State. Lincoln, 1892. P. 5-6. 
would not make it to New York on time for "Missouri's" departure. By then, 4.753.516 pounds of corn had been sent. The rest of the load was bought with the money donated by the committee of the New York Chamber of Commerce. ${ }^{15}$ The steamship belonged to "The Atlantic Transportation Line" that had agreed not to charge freight for the journey. Railroad companies likewise let the donated goods pass without charge, while the telegraph companies transmitted hundreds of campaign-related messages to all corners of the country. The total price of this cargo, including expenditures for transportations, telegraph communication, warehousing, loading, marine insurance, fuel, and crew work during trip was about $\$ 200,000 .{ }^{16}$

On March 15" , "Missouri" departed from New York to Libava, and on this occasion the city's periodicals were very generous in their comments. ${ }^{17}$ According to Edgar's records, donations for this ship had come from inhabitants of all socio-economic levels, from 450 cities and towns located in 25 different states. ${ }^{18}$ Edgar interpreted these statistics as a demonstration of high humanism that was so characteristic for the American people. In his view, American farmers and millers have shown to the whole world their readiness to feed the hungry without expecting anything in return from those who were not only far removed from them geographically, but also far behind them in their level of economic development. ${ }^{19}$

Iowa's inhabitants and the American Red Cross were also successful in their joint effort. When it became evident that the federal aid was not forthcoming, Clara Barton doubled her fundraising efforts, and Iowa became part of the nationwide campaign coordinated by the American Red Cross that was unprecedented in its scale and international reach. In fact, at the state level, the Iowa famine relief campaign was one of the most vigorous. Thanks to the initiative and energy of Alice French, the Iowa women became an integral part of the effort. The international character of the campaign had provided these American women that already had experience in charity work with new opportunities for socialization.

Governor Boies, in consultation with Clara Barton, appointed 12 women to the Iowa Woman's Auxiliary to the Red Cross. These women activists had visited every farm and every household of the state, using house-to-house canvassing - a tactic that was traditionally associated with electoral campaigns. Donations were also solicited at schools, churches, charity concerts and theater shows; Iowa State University offered public charity lectures. ${ }^{20}$ The Iowa press was unanimous in its support for the campaign and published fundraising appeals and the names of no-

\footnotetext{
${ }^{15}$ Northwestern Miller. Feb. 19, 26, 1892. Vol. 33. N 8, 9. P. 266, 302.

16 AVPRI. F. Posol'stva v Vashingtone Op. 512/1. D. 55. L. 30; D. 56. L. 91-93; Northwestern Miller. February 12 and March 18, 1892. Vol. 33. N 7, 12. P. 228, 440 a.

${ }^{17}$ For quotes from New York newspapers, see Northwestern Miller. March 25, 1892. P. 451-452.

${ }_{18}^{18}$ Northwestern Miller. Feb. 26, 1892. Vol. 33. N 9. P. 301-302, 311.

${ }^{19}$ Edgar W. C. Op. cit. P. 13.

20 Barton C. The Red Cross in Peace and War. N.Y.: American Historical Press, 1910. P. 177; Tillinghast B. F. The Women's Gift to Russia // Harper's Weekly. April 23, 1892. P. 402; Report from A. French to Governor Boies, 23 May 1892. // State Archives of Iowa. State Historical Society of Iowa. RG. 043. Governors' Records. G. VIII. Box 37.
} 
table donors. In the Iowan countryside, the size of the corn donations varied from 1 measure to an entire railcar. The overall value of donations in money and kind reached 40 thousand dollars.

Meanwhile, Benjamin Tillinghast wrote an inquiry to Charles Emory Smith, the United States Minister to Russia, and received the following enthusiastic reply: "This movement is timely and altogether characteristic of the liberal and bighearted people of Iowa. The 100.000 bushels of Iowa corn, which they proposed to send in the form of meal, will, I assure you, be most welcome. American corn meal has been quite unknown in Russia but since the present famine began some small quantities have been brought in and made into bread under American directions. I am informed that wherever it has been tried the peasants like it better that their ordinary rye bread". ${ }^{21}$

Smith was basing his reply on the experiences of Colonel Charles Murphy, a former Wisconsin farmer. In late 1891, Colonel Murphy went to Berlin on a commission from the U.S. Secretary of Agriculture, Jeremiah Rusk. His task was to convince the German Army leadership that the American cornmeal was an excellent base for army provisions. When he got the news about the Russian famine, Murphy seized the new opportunity and, after sending cornbread samples to Saint-Petersburg through Charles Emory Smith, came there in person in order to meet with Russian public officials, including the Interior Minister I. N. Durnovo. ${ }^{22}$ Thus, in the early days of the philanthropic campaign, Murphy joined the ranks of those who advocated sending American corn to the famine-stricken regions, even though there was yet no consensus about the merits of this strategy.

By soliciting free services from the railroad, telegraph and insurance companies, Tillinghast ensured that the collected foodstuffs would be sent to the ANRC warehouses in New York without delay. ${ }^{23}$ In a letter to Clara Barton, he made the following evaluation of what he was observing: "For 21 years I have been connected with the press and have been interested in many movements. I have never seen one where lukewarmness was so widespread... From the first this relief movement has interested me deeply because it was outside of politics and creed". ${ }^{24}$

In the District of Columbia, Clara Barton had managed to collect 20 thousand dollars - such was the response of the Nation's capital to the special appeal of the local ANRC chapter. ${ }^{25}$ Of this sum, $\$ 12,651.62$ was spent on the charter of the

${ }^{21}$ Charles E. Smith to Benjamin F. Tillinghast, January 15, 1892. // AVPRI. F. Posol'stvo v Vashingtone. Op. 512/1, D. 737, L. 122.

${ }^{22}$ Saul N.E. Concord and Conflict. P. 352-353.

23 AVPRI. F. Posol'stva v Vashingtone. Op. 512/1. D. 56. L. 89-89 ob., 119, 217; D. 737. L.17, 108; Tillinghast B.F. Final Report of the Russian Famine Relief Commission to the Governor of the State of Iowa, June 1, 1892 г. // State Historical Society of Iowa. State Historical Society of Iowa. RG. 043. Governors' Records. G. VIII. Box 37. P. 4-7.

${ }^{24}$ B.F. Tillinghast to C. Barton, 31 January 1892. // LC. MD. Clara Barton Papers. R. 83.

${ }^{25}$ District of Columbia Auxiliary Red Cross Association. To the Citizens and Residents of the National Capital. February 22, 1891 // NARS. RG 200. Gift Collection. RANRS. 1881-1916. Box 59. 
steamship "Tynehead" that was loaded with "95.656 bushels of corn in bulk, 402 sacks [corn]meal, 731 sacks flour, 10 bags wheat, 9 bags rye and hospital stores." On May $2^{\text {nd }}$ of 1892, "Tynehead" left the New York harbor for Riga, decorated with flags and streamers and loaded with goods that the American women had collected for Russian peasants in spite of bad weather and roads, lukewarm support for the campaign from some, and open opposition from others. The overall contribution from Iowa was worth about $\$ 100,000 .{ }^{26}$ Soon after this event, Tillinghast "asked Edgar what he thought would be the effect of sending four ship loads of American bread stuffs to Russia. [Edgar's] answer was that it would do more to cement friendly relations between Russia and this country than 50 years of diplomacy."27

The fifth and the last steamship of the Russian "Famine Fleet" was outfitted thanks to the activity of the "Christian Herald" magazine, edited by Thomas de Witt Talmage, a Presbyterian pastor from Brooklyn and his friend Louis Klopsch who had a gift for both journalism and business. In March 1892, after Talmage gave a rousing sermon at his church, "Christian Herald" announced a subscription to raise funds that would be spent on foodstuffs for Russian famine relief. The appeal was answered by Americans of all social standings, although the campaign organizers emphasized that the load of this last steamship, "Leo" was paid for largely by low-income contributors. "Leo" was chartered for 7.5 thousand dollars and loaded with 2.130.800 pounds of flour, including the Red Cross contribution from the overflow of the "Tynehead". If the cornmeal sent with "Conemaugh" is added to this account, the "Christian Herald" emerges as the organization that had assembled the largest relief load of all. On June $13^{\text {th }}$ of 1892 , "Leo" left for Russian shores. $^{28}$

All five steamships of the "Famine Fleet" had safely reached the shores of the Russian Empire. The representatives of charity committees that arrived with them and supervised their unloading and the subsequent distribution of wheat and corn grain and flour informed Americans about the joy and hospitality with which they were met in Russia, shared their reflections about the causes of the famine, and also recreated the image of the Russian peasant.

Scholars who have studied this philanthropic movement are unanimous in their conclusions: it has positively contributed to the development of RussianAmerican relations and has actualized Russia's image in the American public consciousness as that of a country that had been historically friendly to the United States. However, these events acquire another important meaning if they are seen

${ }^{26}$ AVPRI. F. Posol'stva v Vashingtone. Op. 512/1. D. 55. L. 30, 101; D. 56. L. 30, 89; The New York World. May 3, 1892; Tillinghast B.F. A Far-Reaching Charity. II // The Midland Monthly. 1894. Vol.1. N 5. May. P. 410; Borzo H.A. Chapter in Iowa-Russian Relations // Annals of Iowa. 1959. Vol. 34. N 8. P. 589-592.

${ }^{27}$ B.F. Tillinghast to C. Barton, 11 June 1892 // LC. MD. Clara Barton Papers. R. 83.

${ }^{28}$ Christian Herald. March 23, 1892. P. 177, 181. See also: Russia's Cry Heard // Ibid. April 13, 1892; Moskovskie vedomosti. 8/20 June 1892. C. 2; Pepper M. Ch. Life-Work of Louis Klopsch. Romans of a Modern Knight of Mercy. N.Y.: The Christian Herald, 1910. P. 15-20; T. De Witt Talmage: His Life and Work. L.,1902. P. 199-200. 
as the first example of citizen diplomacy in the history of these bilateral relations. $^{29}$

The Russian famine of 1891-92 came at the time of America's active integration into the world grain trade. The United States had made important gains from the grain export ban that existed in Russia from the fall of 1891 to the spring of 1892, while US grain exports had significantly increased over this period. ${ }^{30}$ The famine relief movement had provided excellent publicity for the American agricultural cornucopia and had helped the US to expand its corn markets, which now included Russia. And so it was that at the end of the $19^{\text {th }}$ century American corn began to conquer the vastness of Russia, thanks to the philanthropic efforts of the famine relief committees in the "corn states" of Iowa and Nebraska.

\section{“More corn for Bessarabia": teaching American corn science in Russia}

Those in the United States who commented on the famine episodes that occurred in Russia in 1891-92, 1897, and 1907 invariably pointed out that Russia needed to adopt American innovative agricultural methods. Besides donating money, corn and wheat to alleviate hunger in Russia, Americans were also ready and willing to share their knowledge of how to make agriculture prosper.

In the early 20th century, the Zemstvo of Bessarabia made contact with Perry Holden, professor of Iowa State College of Agriculture and the Mechanic Arts, through the agents of the "International Harvester" in Odessa. Bessarabia was the leading corn-growing region of the Russian Empire, ${ }^{31}$ and its local government officials were interested in corn selection and cultivation techniques that Holden taught to Iowa's farmers. Professor Holden, who was unwilling to leave the United States, replied to this inquiry by recommending Louis Michael, who came to Russia in February 1910 and remained in charge of the "More Corn for Bessarabia” project until 1917.

Soon after his arrival to Bessarabia, Michael came face-to face with underthe-table dealing of the Zemstvo's representatives who had launched a press campaign against him in the local newspapers and with the resistance from the majority of Uezd agronomists, who wanted to prevent Michael's interference in their field of activity and did not believe that the peasants were ready for new American methods. The estate owners left day-to-day decisions about their estates to their managers and had no desire to familiarize themselves with new agricultural methods, preferring to buy improved seed corn when they could obtain it. The peasants were more concerned about expanding their parcels than about increasing corn harvests, and saw the productivity of the land as God's gift instead of something that they could actively change. Michael had to recognize that the peculiar national character of Russian peasants made them see the idea of testing their seed

${ }^{29}$ More details about this philanthropic movement can be found in: Saul N.E. Concord and Conflict. P. 355, 361, 362-363; Zhuravleva V.I. Understanding Russia in the United States: Images and Myths. P. 209-258.

${ }^{30}$ Simms J.Y. Impact of Russian Famine 1891-1892 upon the United States // MidAmerica. 1978. Oct. Vol.60. N 3. P. 179-181.

${ }^{31}$ Corn cultivation began in Bessarabia when this region was under the Ottoman rule. 
corn before planting as strange and outlandish: they considered it to be "a foreign fancy" that had no practical use.

Yet, all this opposition had not intimidated the persistent American who had managed to counteract it by making allies among teachers and priests. The chief among them was the Bessarabian marshal of the nobility, state councillor Alexander Nicolaevich Krupenskii. Thanks to his support, Michael managed to obtain funding from the Gubernie Zemstvo and to create the Zemstvo Corn Selection Commission that was headed by Krupenskii and staffed by Germans, a Serbian and a Czech that Michael had invited.

Michael also began to implement his other plan - the organization of school corn clubs, whose members would select and cultivate corn in their school gardens according to the American method and convince their parents of its goodness. Armed with a Russian translation of Holden's "ABC of Corn Culture" 32 written for American farmers, Michael plunged into teaching. He spent the winter of 1910-1911 selecting children from families of different ethnic origins and social status and forming “40 odd Boy's and Girl's clubs”. True to his American values, Michael designed these clubs as miniature Russian imitations of the American "melting pot" and motivated their work by organizing an inter-club competition, whose winners received a monetary award for producing the biggest corn harvest.

This model experience of rationalized corn cultivation had ensured the success of Michael's entire enterprise and had frustrated both the skeptical forecasts made by local agronomists and Zemstvo officials and the peasants' resistance. ${ }^{33}$ In subsequent years, Michael had not only expanded his network of school clubs, but also attracted to his project some local government officials, big estate owners, and young peasants who had managed to significantly increase their corn harvests in a very short span of time. John Grout, the American Consul in Odessa, regularly informed the US Department of State about all these achievements. ${ }^{34}$

Through the "More Corn for Bessarabia" program, Louis Michael promoted the idea that the US and Russia had similarities in their development and created an updated image of the Russian peasants whom he found capable of adopting innovative agricultural methods, in spite of living "in the land known for its famines" and of being the carriers of certain negative traits of the Russian national character. In Michael's view, the activities of his Zemstvo Corn Selection Commission could be compared to the agrarian reform promulgated by Piotr Arkadievich Stolypin, with the only difference being that Stolypin's reform had benefitted broad groups of peasants, while his program was targeted at a select few who

${ }^{32}$ Holden P.G. ABC of Corn Culture. Springfield, Ohio: Simmons Publishing Co, 1906.

33 Michael L.G. More Corn for Bessarabia: Russian Experience 1910-1917. East Lansing: Michigan State University Press; Detroit: Distributed by Wayne State University Press, 1983. P. 13-16, 26-36, 46-50, 60-61, 70-71, 88-89.

${ }_{34}$ Relevant information on this topic can be found in published consular reports: $\mathrm{Al}$ len R.V. Russia Looks at America: The View to 1917. Washington: Library of Congress, 1988. P. 170-171. 
would form the basis for a new class of independent farmers and act as a buffer between the peasant mass and the state authorities. ${ }^{35}$

Louis Michael noted that the benefits of mechanization in agriculture were clearly understood by the Russian peasants, especially the wealthy ones, and that McCormick reapers and other American agricultural machinery and tools were already widely used in the fields throughout the Russian Empire. These agricultural tools made field labors lighter and continued to constitute the main article of US exports to Russia. In 1910, Russia imported its first American tractor, and a growing number of publications in Russian agricultural journals reflected a growing interest for the technical inventions that had a "Made in USA" legend. ${ }^{36}$

\section{Nikita Khrushchev and Roswell Garst: "corn diplomacy» in the Cold War period}

Forty years later, the baton in the relay-race to teach Russians about the American corn passed from Louis Michael to the Iowa farmer Roswell Garst, whose corn farm had greatly impressed the head of the Soviet government, Nikita Sergeevich Khrushchev during his first visit to the US (September 15-27, 1959). This visit occurred after the 1957 launch of the first artificial satellite by the Soviet Union and in the context of a growing Russian-American cultural cooperation that began with an agreement on cultural and scientific exchanges between the U.S. and the Soviet Union that was signed in January 27, 1958 and came to be known as the Lacy-Zarubin Agreemen. ${ }^{37}$

By that time, the American pianist Van Cliburn had already won the First International Tchaikovsky Competition in Moscow and stolen the hearts of the Soviet people, who quickly russified his name into a tender "Vanyechka". Igor Moiseyev's USSR State Folk Dance Ensemble had already made a sensation during its US tour. The Soviet exhibition in New York had already acquainted Americans with the Soviet achievements in industry and science: from gigantic sculptures of Soviet steel-makers to a Sputnik model emitting the famous beep. Meanwhile, the Sokolniki Park in Moscow played host to the American National Exhibition that presented the wonders of the mass consumer culture at the service of humanity and had become history thanks to the Kitchen Debate between the U.S. Vice President Richard Nixon and Soviet Premier Nikita Khrushchev. ${ }^{38}$

On a darker side, before making his historic visit to the USA, Khrushchev had made his Berlin ultimatum. In November 1958, he placed his former allies in the anti-Hitler coalition before a stark choice: either the Western powers signed a German peace treaty and agreed to turn West Berlin into a demilitarized "free city" within six months, or the Soviets would turn control of access over to East

${ }^{35}$ Michael L.G. Op. cit. P. 90.

${ }^{36}$ Allen R.V. Op. cit. P. 172-177.

${ }^{37}$ About the meaning of this agreement see in details: Norman E. Saul, "The Program that Shattered the Iron Curtain: The Lacy-Zarubin (Eisenhower-Khrushchev) Agreement of January 1958, in William Benton Whisenhunt and Norman E. Saul, eds., New Perspectives on Russian-American Relations (N.Y., L.: Routledge, 2016): 229-239.

${ }^{38}$ Ivanian E.A. Kogda govoriat muzy. Istoriia rossiisko-amerikanskikh kul'turnykh sviazei. Moscow: Mezhdunarodnye otnoshenija, 2007. P. 341-366. 
Germany. According to the American scholar William Taubman, "Khrushev's Berlin ultimatum was a way of getting Eisenhower to the table". ${ }^{39}$

On September 18th of 1959, Khrushchev made a speech at the United Nations General Assembly, calling countries and people of the world to a peaceful coexistence and announcing his famous program of complete and universal disarmament, which, in spite of its utopian hues, was quite positively received worldwide. This speech, together with the Camp David negotiations with the U.S. president Dwight Eisenhower, who was also subsequently invited to Moscow, indicated that the "thaw" in the Soviet domestic politics had also slightly melted the ice of the Cold War. Although Eisenhower was quite elusive in his promises, he generally agreed to resume the search for a diplomatic solution to the German question through a summit of the four powers. Taken together with the growing cultural exchange, these developments demonstrated that the two leaders were leaning towards a relative normalization of the US-Soviet relations and were trying to understand the other side's position.

Nevertheless, Khrushchev's conduct during his first US visit was quite contradictory and, at times, extremely aggressive. On the one hand, he was obviously proud to be the first Soviet leader who had been officially invited to the United States. Khrushchev had been desperately seeking Eisenhower's invitation since 1957 and, when it finally came, saw it as a consequence of his own "missile doctrine". At the same time, although the Soviet leader never missed his chance to talk about the Soviet triumph in space and the advantages of socialism over capitalism, he was extremely ill at ease and unsure of himself. The American prosperity filled him with anxiety and desire to look for any excuse to find fault and to fight back. Khrushchev feared that Americans would be looking for ways to humiliate him and would not receive him with due respect. ${ }^{40}$

Oleg Grinevskii, a prominent Soviet diplomat who formed part of Khrushchev's delegation, later shared his impressions: "What Khrushchev wanted to avoid most of all was to look like an ingenious simpleton in front of the cunning capitalists, who, like circus magicians, presented him with magic tricks out of a hat and showed him all kinds of prosperity miracles that could be found in their rotting world. His team of counsellors and assistants-Adzhubei, Satiukov, Ilyichev and others - had talked his ears off with such warnings. They insisted that 'the times had changed. Peter the First went to the West as a student, in his modest carpenter attire. But you, Nikita Sergeevich, are going to America to teach. Any American general would gladly turn his coat in order to get but a glimpse of the Soviet space and interplanetary launching pads, with Soviet spaceships taking off towards the stars ...' All this nonsense was in Khrushchev's head as he

${ }^{39}$ Taubman $W$. Khrushchev. The man and his era. N.Y., L.: W. W. Norton \& Company, Simon \& Schuster, 2003. P. 403.

${ }^{40}$ Taubman W. Khrushchev. Pp. 396-439. See also: Zubok V.M. Neudavshaiasia imperiia: Sovetskii Soiuz v kholodnoi voine ot Stalina do Gorbacheva. Moscow: Rossijskaya politicheskaya ensiklopediya, 2011. P. 208-209 
journeyed through America, and a deep trench formed between him and the USA as a result." ${ }^{41}$

Nevertheless, as Grinevskii rightly notes, ${ }^{42}$ Khrushchev's head was also a battlefield between a dogmatic communist and a pragmatic peasant who, upon Khrushchev's return from the United States, took it upon himself to recreate in the Soviet Union all the good things that he had seen in the American daily life. This peasant alter ego manifested itself with singular strength in Khrushchev's relationship with the American farmer Roswell Garst.

Khrushchev's interest in Garst was no accident. This farmer-millionaire, as the American periodicals called him, was "an American revolution in agriculture". His two thousand hectares of land in Coon Rapids, Iowa had become the birthplace of various agricultural innovations; one of them was hybrid corn, which was the product of inbreeding and crossbreeding. Garst and his business partner Charles Thomas owned a big joint-stock company that produced hybrid corn seeds and formed part of the "Pioneer" - a national leader in seed production that, apart from hybrid corn varieties, also produced new breeds of chicken and pigs. Garst was also experimenting with new fertilization methods and skillfully used silage — a hash made out of corn cobs and other ingredients - as a feed for his livestock. ${ }^{43}$

The story of Khrushchev's acquaintance with Garst had begun four years earlier. In January 1955, at the plenary meeting of the CPSU Central Committee Khrushchev made a speech about livestock production, in which he made numerous references to the American experience as an example for the USSR to follow. On February $8^{\text {th }}$, a summary of his speech appeared in "The New York Times" and was then reprinted in "The Des Moines Register" of Iowa. Two days later, in an editorial that won him next year's Pulitzer Prize, its editor Lauren Soth made a provocative proposal. Promising to hide none of Iowa's "secrets," he invited Russians to tour Iowa for "the lowdown on raising high quality cattle, hogs, sheep, and chickens." In turn, Iowa farm experts could visit the Soviet Union and share their know-how. ${ }^{44}$ Thus the "corn" state of Iowa had once more become the agent of Russian-American rapprochement.

In July 1955, a Soviet delegation headed by the Deputy Minister of Agriculture Vladimir Matskevich came to the USA and visited Roswell Garst at his farm, which was among Iowa's most prosperous, and at "Garst\&Thomas Company"one of the largest of its kind in Iowa. Iowa's residents met the Soviet specialists with open arms, showed them everything there was to see and provided them with detailed explanations and a pile of manuals. Upon the delegation's return to the USSR, Matskevich compiled a 400-page report that, unbeknownst to him, had a lot in common with what Louis Michael taught to Bessarabian peasants half a

${ }^{41}$ Grinevskii O.A. Tysiacha i odin den' Nikity Sergeevicha. Moscow: Vagrius, 1998. P. 57-58.

${ }^{42}$ Ibid., P. 98.

${ }^{43}$ Missionary of the Food. Roswell Garst // The New York Times. September 23, 1959.

${ }^{44}$ The Des Moines Register. February 10, 1955 (editorial). 
century earlier. Like Michael, Matskevich paid special attention to the calibration and selection techniques for corn seeds and the cultivation of high-yield hybrid corn varieties. His main conclusion was that the American corn cultivation methods could resolve the food problem in the Soviet Union and also dramatically increase meat production, since the best silage for livestock could be made out of young corn leaves, stalks and ears. Matskevich's report also had a special section that described Garst's farm, and Khrushchev first got to know Garst through this document. $^{45}$

Roswell Garst was among the twelve American farmers (five of them from Iowa) who dared to travel to the other side of the "iron curtain" in October 1955, defying the trading ban that the US Department of State still had in place against the Soviet Union and the danger of being accused of having links with Communists. Garst visited the All-Union Agricultural Exhibition in Moscow and then stopped in Kiev and Odessa on his way to Khrushchev' summer residence in Yalta - a visit that he made on Khrushchev's personal invitation. During his tour, the American entrepreneur lost no opportunity to study how the Soviets cultivated corn and produced hybrid seeds, noting the gap between the Soviet agricultural capacity and the food demands of the growing population, and demonstrated his readiness to teach the $\mathrm{ABC}$ of the American corn science: production of hybrid seeds, fertilization, irrigation, mechanization, and the use of agricultural chemicals.

During his interview with Garst, Khrushchev made him a proposal: "Let us trade. We can buy some of your hybrid corn seeds. But keep in mind that our country is vast - we plant millions of hectares of corn. Will you be able to sell us enough hybrid corn seed for such a large area? Will we be able to pay for them, even if you could sell us enough? Besides, we have our own hybrids of good quality. So, what we should do is not only trade, but also exchange expertise. We will give you our Soviet hybrids and their breeding lines, and you give us your hybrids and breeding lines in exchange." To this Garst replied that he could not share his breeding lines, because they constituted a trade secret, and instead offered a different deal: "Send your agronomist to my farm and let him see how we produce our hybrid corn seeds. Send over your livestock specialist so that he can see how we feed our meat cattle. Send your biochemist so that he can learn how we fix atmospheric nitrogen and make urea that is mixed into silage together with corn cobs and molasses. Send your machine operator over to my farm and let him work in the fields at my son's side so that he can see for himself that corn production can be organized in such a way that one person can work 100 hectares and six people-800 hectares." 46

In the end, the two men came to an agreement that Garst would sell to the Soviet State 5 thousand tons of different varieties of corn seed and add in some of

${ }^{45}$ Khrushchev S.N. Nikita Khrushchev: Reformator. Moscow: Vremya, 2010. P. 239240. Brown P.N. Diplomatic Farmers: Iowans and the 1955 Agricultural Delegation to the Soviet Union // The Annals of Iowa. 2013. Vol 1. N 72. Winter. P. 31-62.

${ }^{46}$ Quote from Adzhubei A. et al. Litsom k litsu s Amerikoi. Rasskaz o poezdke N.S. Khrushcheva v SShA. Moscow: Politizdat, 1960. P. 338-339. 
his pedigree seeds as a bonus on this deal. These pedigree seeds were later used to produce hybrids at the Odessa breeding station. Besides, the Soviet Union bought the technology for building a corn-cleaning and calibrating plant in the Krasnodar region. The enterprising Garst had his hands free to make these deals, since he had obtained a termless export license from the State Department before leaving for the USSR. Yet, although he had acted first and foremost as a businessman - the Soviet State had paid him in gold for his seeds, eventually his frequent trips to Soviet Russia did attract the FBI's attention: he was later called in for explanations and had to convince the FBI that he was no Communist.

While he had personally benefitted from his agreement with Khrushchev, Garst had also managed to break the ice in the Soviet-American trade relations and became an active advocate for a peaceful collaboration with the USSR and the development of business ties and knowledge exchange between Americans and Russians. In 1958, he addressed the Soviet agricultural delegation with the following words: "The main reason for your success is the enormous work that you have done in the sphere of popular education and professional cadre preparation. What you need now is to make contacts that would help you adopt agricultural innovations and increase the production of grains, meats and other foodstuffs." ${ }^{47}$

Garst made three more visits to the Soviet Union and met with Khrushchev one more time, in Sochi, in spring of 1959. On Khrushchev's request, he had even gone to Kazakhstan to see the virgin lands that reminded him of the vastness of his native Iowa. In the Krasnodar region, Garst instructed a kolkhoz foreman who did not want to use fertilizers about the correct ways to grow corn. The informal relationship between Khrushchev and Garst had developed into a true friendship, notwithstanding the Cold War. ${ }^{48}$ Nikita Sergeevich Khrushchev who had not forgotten his solid peasant upbringing came to a perfect understanding with Roswell Garst and dreamed of turning corn into a true queen of the Soviet fields.

During his US journey, Khrushchev paid a two-day return visit to his American farmer friend (September 22-23, 1959). According to the eyewitnesses, the days he spent in the rich and flourishing Iowa, in the heart of the US "corn belt" were the most successful part of Khrushchev's visit. Receptions given to Khrushchev in Washington, New York, Los Angeles, and San Francisco had not come anywhere close to the warm and friendly welcome that he had received in Iowa, whose periodicals went as far as declaring September 22 nd "the Day of Khrushchev in the Mid-West". ${ }^{49}$ Khrushchev himself told Henry Cabot Lodge, the official host to the Soviet leader, that "it has been the highlight of the whole trip". 50

Khrushchev hoped that by adopting American agricultural methods the Soviet Union would "catch up with America and surpass" its levels of food production. In his address to Iowa's residents, he championed peaceful coexistence and competition. This call could not but please them, since Khrushchev also recog-

${ }^{47}$ Quoted from Adzhubei et al., op. cit., P. 340.

${ }^{48}$ Khrushchev S.N. Nikita Khrushchev: Reformator. P. 244-245.

${ }^{49}$ Grinevskii O.A. Tysiacha i odin den' Nikity Sergeevicha. P. 77.

50 Weherwein A.C. Iowa Skeptical, but Enjoyed Visit // The New York Times. September $25,1959$. 
nized that at that moment Iowan farms were producing significantly more corn and meat than Kuban' kolkhozes. Anticipating Khrushchev's reaction to what he would see in Iowa, American journalists wrote that Iowa was precisely the place where the Soviet leader could personally appreciate the achievements of the American agricultural revolution and see for himself what levels of prosperity a capitalist society could reach. ${ }^{51}$

Khrushchev's coming had briefly made Garst's farm the center of attention not only of the entire United States, but also of the whole world. So many newspaper men came there, that, in the words of "The New York Times" correspondent James Reston, "there were more photographers in the trees than birds". ${ }^{52}$ In late August 1959, the State Department received 471 media accreditation request to cover Khrushchev's visit. ${ }^{53}$

The testy Garst got so fed up with the press representatives that he threw silage and corn cobs at them and even gave one of them a kick. In the end, the National Guard and the Army together with the State Department officials who accompanied Khrushchev had to form a human chain around Garst and his highprofile visitor, so that the latter could examine the farm without further interruptions. ${ }^{54}$ Khrushchev's son Sergei later recalled: “Garst had completely stunned my father with the show of his achievements. Father just kept saying: 'That's what we need to do at home'." 55

Much as the journalists had bothered Garst, the press coverage of Khrushchev's visit provided excellent publicity for his prosperous farm and allowed him to share his agricultural expertise with the entire world. In one of the numerous articles that "The New York Times" published on the subject, Garst appeared as a missionary of the American agricultural revolution that had mobilized science and technology to produce such innovations as hybrid corn varieties, synthetic fertilizers, and pesticides. To promote these innovative agricultural methods so that more products could be obtained with less human labor was what Garst saw as his goal. This man symbolized the American prosperity and he chose the Soviet Union as the object of his agricultural mission, in spite of the "iron curtain" and of the Cold War. Khrushchev dreamt of providing the Soviet people with plenty of meat, and Garst had made a commitment to help him in this task. In an interview to "The New York Times", he made the following statement: "Mr. Khrushchev's primary interest is to find out why 12 per cent of the people of the United States can produce enough food for the 100 per cent and with a diet high in the meat type of human protein. He is interested in finding out how to produce a better diet with

\footnotetext{
${ }^{51}$ Weherwein A.C. Premier to Find the Iowa Doors Open // The New York Times. September 10, 1959.

${ }_{52}$ Khrushchev's Odyssey // The New York Times. September 24, 1959.

${ }^{53}$ Lee H. Roswell Garst: A Biography. Ames: Iowa State University Press, 1984. P. 223.

${ }^{54}$ A photographer from "Associated Press" had captured this moment in a photo that was then widely reproduced in the American press.

${ }^{55}$ Khrushchev S.N. Nikita Khrushchev: Reformator. P. 247.
} 
less and less people. This is what I basically intend to help him discover. This is what he basically wants to know". ${ }^{56}$

During their first meeting in Crimea Garst had already excited Khrushchev's imagination with his tales of how granulated fertilizers could be used to grow corn. Now, at his home base, he could give Khrushchev a practical demonstration of how the use of nitrogen-rich mineral fertilizer instead of the traditional planting of nitrogen-fixing leguminous plants between the rows of corn increased corn yields. Khrushchev, whose faith in corn as the most productive cereal known to human beings was as great as Garst's, listened and watched with rapture. The trench method that Garst used for turning corn cobs and stalks into silage for livestock had also filled him with great enthusiasm. ${ }^{57}$ Meanwhile, Garst's wife was on her own international mission, as she acquainted Khrushchev's wife with all the exciting details of American provincial life. ${ }^{58}$

The American press had given Garst his due for having skillfully dispelled a huge "diplomatic storm cloud", by giving the Soviet leader a guided tour of the real America and a taste of true American hospitality. ${ }^{59}$ Garst's corn calibration plant in the town of Coon Rapids became the site of the famous photo, in which the American farmer and the Soviet leader are standing side by side with corn ears in their hands. In fact, American periodicals had published a whole series of photos with Khrushchev holding a bunch of corn ears, as if they were flowers. Even the "Life" magazine had considered the photo of a laughing Khrushchev standing next to Garst with a corn ear in his hand to be worthy of its cover. ${ }^{60}$ This cover photo seemed to confirm Garst's opinion that "two farmers could settle the problems of the world faster than diplomats". ${ }^{61}$

Later on, Garst explained his motivation in more general terms: "I think from our own selfish interests, we cannot effort to have one-third of the world possess the atomic bomb and the hydrogen bomb and nothing else - to be hungry at the same time. This is too great a temptation". ${ }^{62}$ Just as it happened at the end of the 19th century, in the middle of the 20th century, American farmers were chosing Russia as the object of their messianic impulse, laying aside ideological and political considerations.

In his speech at an official dinner reception in Des Moines, Governor Herschel Loveless stressed the key role of the Corn State of Iowa in the exchange of agricultural expertise between the USA and the USSR that had begun four years earlier and had opened the door for a wider cooperation: "These [agricultural]

${ }^{56}$ Missionary of Food. Roswell Garst // The New York Times. September 23, 1959.

${ }^{57}$ Khrushchev S.N. Nikita Khrushchev: Reformator. P. 242-243; Adzhubei et al., op. cit., P. 343-346.

${ }_{58}$ Asbury E.E. Mme. Khrushchev will Tour Town // The New York Times. September 23, 1959 .

${ }_{59}$ Lee H. Roswell Garst. P. 226.

${ }^{60}$ Life. October 5, 1959 (cover).

${ }^{61}$ Stevenson Reports Khrushchev Hints at Give in Negotiations. Chat Held in Iowa // The New York Times. September 24, 1959.

${ }^{62}$ Roswell Garst, 79, Khrushchev's Farm Host in 1959 // The New York Times. November 7, 1977. 
exchanges have led to broader exchanges in cultural, educational, scientific fields between Americans and citizens of the Soviet Union. So, in a sense, Iowa has led the way to more people-to-people contacts between our two great countries". ${ }^{63}$ In other words, as the local periodicals never got tired of repeating on the occasion of Khrushchev's visit, Iowa's warm and humid climate that was so good for corn cultivation had also managed to melt the ice of the Cold War". The American national press deemed Khrushchev's visit to be quite a success and an ice-breaker for Soviet American relations. ${ }^{64}$

Meanwhile, the Soviet chroniclers spared no praise and called the Soviet leader's trip to the US an outright “triumph". Upon Khrushchev's return, his sonin-law, Aleksei Adzhubei and a group of Soviet journalists rapidly and eagerly produced a propaganda book entitled "Face to face with America". On the pages of this book, the First Secretary of the CPSU Central Committee appeared before the Soviet and the Eastern European audiences as a peace fighter, a great speaker, and a skilled negotiator. The book does much to confirm the suspicions expressed by James Reston in his "New York Times" article that described Khrushchev's visit to Iowa in all its picturesque details: "In a world-wide propaganda battle, this is not frivolous nonsense. It is deadly serious, for while it was inevitable that Moscow would be given much raw material for propaganda in the neutral countries, it was not inevitable that clumsy administration should make things worse." ${ }^{65}$

This propaganda effort went hand in hand with the onset of what became a veritable "corn epic". Throughout the entire territory of the Soviet Union-from Kazakhstan to Taimyr - corn plantations began to displace wheat, rye, and fodder crops. Efforts to grow corn were not limited to the southern regions, but were also made in climatic zones that were completely unsuitable for corn cultivation. In the end, it became obvious that the fantastic grain so zealously promoted by Khrushchev could not replace traditional cereals. What is more, as an overreaction to this policy, after Brezhnev's rise to power in 1964, even the regions where corn had been successfully cultivated since the times of the Russian Empire stopped planting it completely. Neither could Khrushchev achieve the main objective of his corn crusade: the Soviet Union did not surpass the USA in meat production. The taste of corn that generations of Soviet people who grew up after Khrushchev's visit with Garst learned to love from their childhood was not the taste of sweet corn that is so well known and loved throughout the world. The Soviet "queen of the fields" was meant for feeding cows and pigs, because in their effort to increase meat production the Soviet authorities planted no other varieties. It is obvious, that the source of these problems did not lie in the American experience, but in the inability to adapt it rationally and productively to a different context.

${ }^{63}$ Texts of Speeches made by Government Loveless, Lodge and Khrushchev at Dinner at Des Moines // The New York Times. September 23, 1959.

${ }^{64}$ See, for example: Khrushchev after His U.S. Tour // The New York Times. September 27, 1959; Mr. K Due in Moscow Today; Trip Praised // The Los Angeles Times. September 28, 1959.

${ }^{65}$ Reston, op. cit. 
On the other hand, the six months that followed Khrushchev's visit to the USA seem to have been the "warmest" time of the Cold War. The intensive negotiations on the German question between Khrushchev and Eisenhower at his summer residence of Camp David had raised hopes that a détente in Soviet-American relations was indeed possible, even though these negotiations did not produce any specific agreements. Nevertheless, these hopes soon proved to be an illusion, and the "warming" of bilateral relations had ended soon after it began. The American U-2 incident had damaged Khrushchev's relations with Eisenhower beyond repair and was followed by the construction of the Berlin wall, the placement of Soviet missiles in Cuba, and the Caribbean Crisis that had pushed the world to the brink of a nuclear disaster.

William Taubman, one of the most authoritative scholars of "the Khrushchev epoch", thinks that “in many ways Khrushchev's trip was a success: his very presence in the citadel of capitalism; the way many ordinary Americans received him; 'progress' enough on Berlin to justify the president's endorsing the summit Khrushchev had so long been seeking. But the glass was also half empty. The progress in Berlin was more image than substance: Khrushchev's personal failings undermined his diplomacy", ${ }^{66}$

The opinions of those American researchers who consider Khrushchev's visit to have been fruitless or a failure altogether are contested by Kyle A. Kordon, an American historian who bases his conclusions primarily on Khrushchev's own memoirs and the writings of his son. Kordon rightly notes that in order to achieve the kind of mutual understanding that Khrushchev sought the two leaders first had to exchange information that would reveal the each side's position and motivations. Seen in this light, "the spirit of Camp David" provided an indispensable base for the return to good-faith diplomatic relations between Russia and the United States, to the situation where one side would truly listen to the other. What Khrushchev was able to achieve, as he got to know Americans and their manner of life and thought, was precisely a better understanding of the American position. ${ }^{67}$ Alexander Fursenko and Timothi Naftali also include in list of benefits of Khrushchev's visit the fact that he made a genuine effort to put in practice in the Soviet Union all things good that he had seen in the United States. ${ }^{68}$

Even though Khrushchev's visit had not brought about the much-awaited détente in Soviet American relations, his friendship with "the corn diplomat" Garst had not come to an end. The two men kept writing to each other. In May 1963, Garst came to the Soviet Union and met Khrushchev once more. First, he negotiated with the head of the Soviet State in Kremlin, in the presence of I. T. Volovchenko, the Minister of Agriculture, and then had dinner with Khrushchev

${ }^{66}$ Taubman $W$. Khrushchev. P. 425.

${ }^{67}$ Kordon K.A. Khrushchev Comes to America: The Advent of Mutual Understanding // Voces Novae: Chapman University Historical Review. 2009. Vol. 1. N 1. P. 147-151, 166-169.

${ }^{68}$ Fursenko A., Naftali T. Khrushchev's Cold War: The Inside Story of an American Adversary. New York and London: W.W. Norton \& C, 2006. P. 242-245. 
at his summerhouse. ${ }^{69}$ After his demotion, Khrushchev continued to experiment with the hybrid corn seeds that his old friend Roswell Garst would send him from the United States. ${ }^{70}$ Now that he no longer had all the arable lands of the country at his disposal, he had to limit his experiments to a small plot of land at his summerhouse.

Sergei Khrushchev assured his readers that Iowans have kept a very warm memory of his father's visit. An Iowa governor had told him: "Your father has made our state famous . . . And our corn as well." 71 We would do well to add to this statement that Roswell Garst had also become a celebrity thanks to the First Secretary of the Soviet Union Communist Party. In 2009, Iowa celebrated the 50th anniversary of Khrushchev's visit with a conference entitled "Citizen Diplomacy in U.S.-Russia Relations", publications in the local press, a parade of both antique and modern farm machinery down the Main Street and the creation of a museum on Garst's farm. ${ }^{72}$

At the eve of this celebration, Garst's granddaughter Rachel made the following comment to the correspondent from "Rossiyskaya Gazeta": "The more we talked about this idea, the more people became interested in participating. Our organizing committee already includes farmers and businessmen, the Iowa State Historical Society, and many other people who are interested in further strengthening Russian-American relations. My grandfather's house and farm have been added to the US National Heritage list. The purpose of our media campaign is to remind the people about the enormous importance of Khrushchev's visit to America. ... We are very proud of our friendship with Russian people and want to develop it further. We also hope that these kinds of contacts will help to maintain peace between our countries." 73

During this anniversary celebration, it was decided that Iowa needed a theater play about these long-gone days and the events that warmed Russian and American hearts in the harsh climate of the Cold War. The play that was appropriately titled "Peace through Corn" was first presented to the public on January $26^{\text {th }} 2011$. Its script was written by Cynthia Mercati and is based on memoirs, press accounts, and letters that the two men sent to each other. It is a story of friendship between two very different people that, according to producer Robert Ford, had nothing but corn in common, yet corn made their friendship possible. ${ }^{74}$

\footnotetext{
${ }^{69}$ Khrushchev and Iowan Renew Talk of Farms // The New York Times. May 11, 1963.

${ }^{70}$ Khrushchev is Living at Dacha He Had as Premier // The New York Times. January 9, 1965.

${ }^{71}$ Khrushchev S.N. Nikita Khrushchev: Reformator. P. 248-249.

${ }^{72}$ 50th Anniversary of Khrushchev's Visit to Iowa is Celebrated. International Bonds Developed as a Result of Friendship between Soviet Premier Nikita Khrushchev and Iowa Farmer Roswell Garst // Prairie Farmer. August 31, 2009 // http://farmprogress.com/story50th-anniversary-of-khrushchevs-visit-to-iowa-is-celebrated-9-31177

${ }^{73}$ Khrushchev v poliakh // Rossiyskaya gazeta. 2 April 2009 // http://www. rg.ru/2009/04/02/hrushev.html

74 Theater of Iowa in US Stages Play about Khrushchev // http://rt.com/art-and-culture/khrushchev-garst-corn-theatre
} 
As he shared his knowledge about corn cultivation, Roswell Garst was acting as a citizen diplomat, just as the Iowa and Nebraska farmers and Louis Michael did before him. Even though Khrushchev's visit to Iowa had not led to tangible Soviet-American agreements and the Soviet kolkhozes had not adopted Garst's methods, it was not made in vain. While it is true that Americans had once more acted as Russia's teachers, sharing the secrets of their success and prosperity with a backward country - be its name the Russian Empire or the Soviet Union, the history of the corn diplomacy has an important lesson to teach us. Its true importance lies in that people on the two sides of the Atlantic got a chance to get to know and to understand each other better, which was of paramount importance during the Cold War.

\section{Bibliography}

Adzhubei A. et al. Litsom k litsu s Amerikoi. Rasskaz o poezdke N.S. Khrushcheva v SShA. Moscow: Politizdat, 1960.

Allen R.V. Russia Looks at America: The View to 1917. Washington: Library of Congress, 1988.

Barton C. The Red Cross in Peace and War. N.Y.: American Historical Press, 1910.

Borzo H.A. Chapter in Iowa-Russian Relations // Annals of Iowa. 1959. Vol. 34. N 8. P. 561-596.

Brown P.N. Diplomatic Farmers: Iowans and the 1955 Agricultural Delegation to the Soviet Union // The Annals of Iowa. 2013. Vol 1. N 72. Winter. P. 31-62.

Blankenburg R. Philadelphia and the Russian Famine of 1891 and 1892. Letters from Russia to the Philadelphia "Ledger", "Times" and "Inquirer". Philadelphia: Russian Famine Relief Committee, 1892.

Edgar W.C. The Russian Famine of 1891 and 1892: Some Particulars of the Relief Sent to the Destitute Peasants by the Millers of America in the Steamship Missouri. Minneapolis: Millers and Manufacturers Insurance, 1893.

Foglesong D.S. The American Mission and the "Evil Empire". The Crusade for a "Free Russia" since 1881. N.Y.: Cambridge University Press, 2007.

Fursenko A., Naftali T. Khrushchev's Cold War: The Inside Story of an American Adversary. New York and London: W.W. Norton \& C, 2006.

Grinevskii O.A. Tysiacha i odin den' Nikity Sergeevicha. Moscow: Vagrius, 1998. Holden P.G. ABC of Corn Culture. Springfield, Ohio: Simmons Publishing Co, 1906.

Ivanian E.A. Kogda govoriat muzy. Istoriia rossiisko-amerikanskikh kulturnykh sviazei. Moscow: Mezhdunarodnye otnoshenija, 2007.

Khrushchev S.N. Nikita Khrushchev: Reformator. Moscow: Vremya, 2010.

Kordon K.A. Khrushchev Comes to America: The Advent of Mutual Understanding // Voces Novae: Chapman University Historical Review. 2009. Vol. 1. N 1. P. 147-180.

Lee H. Roswell Garst: A Biography. Ames: Iowa State University Press, 1984. 
Michael L.G. More Corn for Bessarabia: Russian Experience 1910-1917. East Lansing: Michigan State University Press; Detroit: Distributed by Wayne State University Press, 1983.

Pepper M. Ch. Life-Work of Louis Klopsch. Romans of a Modern Knight of Mercy. N.Y.: The Christian Herald, 1910.

Reeves F.B. Russia Then and Now. 1892-1917. N.Y., L.: Putman's, 1917.

Saul N.E. Concord and Conflict. The United States and Russia, 1867-1914. Lawrence: University Press of Kansas, 1996.

Norman E. Saul, "The Program that Shattered the Iron Curtain: The Lacy-Zarubin (Eisenhower-Khrushchev) Agreement of January 1958, in William Benton Whisenhunt and Norman E. Saul, eds., New Perspectives on Russian-American Relations (N.Y., L.: Routledge, 2016): 229-239.

Simms J.Y. Impact of Russian Famine 1891-1892 upon the United States // MidAmerica. 1978. Oct. Vol.60. N 3. P. 177-184.

Taubman W. Khrushchev. The man and his era. N.Y., L.: W. W. Norton \& Company, Simon \& Schuster, 2003.

Williams W.A. The Roots of the Modern American Empire: A Study of the Growth and Shaping of Social Consciousness in a Marketplace Society. N.Y.: Random House, 1959.

Zhuravleva V.I. Understanding Russia in the USA: Images and Myths. 18811914. Moscow: RGGU, 2012.

Zubok V.M. Neudavshaiasia imperiia: Sovetskii Soiuz v kholodnoi voine ot Stalina do Gorbacheva. Moscow: Rossijskaja politicheskaja jenciklopedija, 2011.

\footnotetext{
About author:

Victoria I. Zhuravleva, Doctor of History, Professor of American History and International Relations at the Department of Area Studies and Foreign Policy, Vice-Dean of the Faculty of International Relations and Area Studies, Director of the Program on American Studies, Russian State University for the Humanities, Moscow, Russia. She is the author of Understanding Russia in the United States: Images and Myths (in Russian).
} 